\title{
PERAN ADVOKAT DALAM PEMBANGUNAN HUKUM INDONESIA
}

\author{
Mochamad Mansur ${ }^{1}$
}

\begin{abstract}
In everyday there are few terms that used to interpret this law profession. Some are termed the lawyers and also use the phrase of legal advisor, lawyer or advocate in Malaysia known as Peguam. The advocates, lawyer and legal advisor terms in english languange also can be called as trial lawyer or specifically in America known as attorney at law as well as in the United Kingdom known as barrister, and the role given by the lawyer that using the legal advisor terms in America known as counselor at law or also solicitor in United Kingdom. In constitution number 18 of 2003 about advocate, the word advocate is used in chapter I about General Conditions explained, Advocate is a person who work as legal professionals, both inside and outside of the court who fulfills the requirements under the provisions of this law. In practice the law profession is not only undertaken by the advocate during examination process at the level of investigation and examination in court (litigation process), however the role of advocate is also seen outside the court. The need for advocate legal services outside the court process is currently increasing, in line with growing needs of the community law, especially in existence that is increasingly open in association between nations. Through consulting services, negotiation and in making contracts for community empowerment and national law reform, especially in the economics and trade, including settlement of disputes outside of the court. Advocates as one element of the justice system is one of the pillars in upholding the rule of law and the human right. Advocates are a noble profession that is closely related to humanity. Increasing capital flows and foreign investment, especially among business people in ASEAN member countries (inter-ASEAN trade and investment), logically it will be followed by an increase in the need of lawyers or legal advisor services. This profession is important in providing direction and legal advices, including the assistance needed by business people properly and protected in Indonesia. Vice versa, when Indonesian business people decided to develop the investment and production activites, for example to Thailand or other ASEAN countries. Indonesian business people will need the services of lawyers or legal advisor who understand the provisions of Thailand laws. The challenges of the advocates basically lies mostly on advocates and the professional advocate commuity to how far the advocates can respond to the problems of the community in his environment. Another challenge is the political climate factor wich is not conducive to developing the role of advocates, for this reason, there is a need for a socialization of the function of the existence of an advocate role both for officials and the general public. These challenges will be increasingly complex when professional skill and the enthusiasm for learning from the lawyers do not grow in accordance with the demands of the global era, including the mastery of foreign languages as a key to opening communication with foreign relation. For this reason, the relationship network with IBA (International BAR Association), ABA (American BAR Association), Lawyer Commitee For Human Rights and the like needs in the era of globization.
\end{abstract}

Kata kunci: Advokat, Pembangunan Indonesia, hukum

${ }^{1}$ Dosen Fakultas Hukum Universitas Bojonegoro 


\section{PENDAHULUAN}

Dalam keseharian terdapat beberapa istilah yang digunakan memaknai profesi hukum yang satu ini. Ada yang mengistilahkan pengacara ada juga yang menggunakan panggilan advokat dan ada juga yang menggunakan frasa penasehat hukum, di negara Malaysia pengacara atau advokat dikenal dengan istilah peguam. Istilah advokat, pengacara dan penasehat hukum yang dalam bahasa Inggris disebut trial lawyer atau secara spesifik di Amerika dikenal dengan istilah attorney at law serta di Inggris dikenal istilah barrister, dan peran yang diberikan oleh lawyer yang menggunakan istilah konsultan hukum yang di Amerika dikenal dengan istilah counselor at law atau di Inggris dikenal dengan istilah solicitor.

Berawal dari seorang tokoh (orang termuka) di zaman Romawi Antik (jauh sebelum Tahun Masehi), yaitu Patronus, profesi advokat dikenal sebagai pekerjaan terhormat dan dihargai hingga saat ini. Patronus mengambil peran membela orangorang yang membutuhkan keadilan dalam sistem kerajaan dan kekaisaran saat itu. Maka Patronuslah yang mengambil peran advokat pertama di dunia. Patronus menjadi sandaran dan harapan publik untuk mendapatkan keadilan atas semua sengketa, mulai sengketa keluarga, sampai pada sengketa eknomi, properti, dan pidana. $^{2}$

Dalam undang-udang nomor 18 tahun 2003 tentang Advokat, digunakan kata Advokat yang di dalam Bab I tentang Ketentuan Umum dijelaskan, Advokat adalah orang yang berprofesi memberi jasa hukum, baik di dalam maupun di luar pengadilan yang memenuhi persyaratan berdasarkan ketentuan undang-undang ini.

Keberadaan profesi advokat tidak dapat dipungkiri eksistensinya sejak zaman penjajahan hingga pada era kemerdekaan dan berkembang terus hingga saat ini, walaupun disatu sisi ditemukan bahwa ketersediaan tenaga advokat banyak terkonsentrasi di kotakota besar dan sebaliknya di daerah-daerah keberadaan mereka sangat sedikit, bahkan di daerah-daerah terpencil sangat susah mencari orang berprofesi sebagai advokat. Keberadaannya sangat penting karena memiliki peran dan fungsi yang urgen dalam sebuah proses penegakan hukum menjadikan profesi advokat perlu mendapat pengaturannya dalam suatu aturan hukum, peraturan perundang-undangan yang mengatur institusi advokat perkembangannya sudah sejak zaman penjajahan. Berdasarkan pada peraturan perundang-undangan peninggalan zaman kolonial, seperti ditemukan dalam Reglement op de Rechterlijke Organisatie en het Beleid de Justitie in Indinesia (Stb. 1847 : 23 jo. Stb. 1848 : 57), pasal 185 sampai pasal 192 dengan segala perubahan dan penambahannya, kemudian Bepalingen betreffende het kostuum der Rechterlijke Ambtenaren dat der Advokaten, procureus en Deuwaarders (Stb. 1848 : 446 jo. Stb. 1922 : 523), dan Vertegenwoordiging van land in rechten (K.B.S 1922 : 522).

Profesi advokat sesungguhnya sarat dengan idealisme. Sejak profesi ini dikenal secara universal sekitar 2.000 tahun yang lalu, ia sudah dijuluki sebagai officium nobile artinya profesi yang mulia dan terhormat. Profesi advokat itu mulia, karena ia mengabdikan dirinya sendiri, serta ia berkewajiban untuk turut menegakkan hakhak asasi manusia. Di Hindia Belanda (Indonesia) sampai pertengahan tahun 1920an, semua advokat dan notaris adalah orang Belanda. Hal ini pula yang memengaruhi mengapa perkembangan advokat pasca kemerdekaan Indonesia masih berjalan lambat. Mengenai hal ini, Daniel S. Lev, berpendapat bahwa besar kecilnya jumlah advokat pribumi tergantung kepada kombinasi ideologi pemerintah dan

\footnotetext{
${ }^{2}$ Theodorus Yosep Parera, Advokat dan Penegakan Hukum, Genta Press, Jakarta, 2016, h. 1.
} 
kebijaksanaan ekonomi kolonialnya, (Daniel S. Lev, 1990). ${ }^{3}$

Sejarah mencatat hingga pada tahun 1940 terdapat hampir tiga ratus orang Indonesia asli menjadi ahli hukum sampai pada pendudukan Jepang. Para advokat Indonesia angkatan pertama menetap di Belanda sebagai advokat. Di antara empat puluh orang Indonesia yang meraih gelar sarjana hukum di Leiden, tidak kurang dari enam belas orang menjadi advokat sepulang ke Indonesia.

Perubahan yang monomental terjadi ketika diundangkannya undang-undang nomor 18 tahun 2003 tentang Advokat dan dinyatakan berlaku, ini menjadi angin segar bagi semua stakeholder yang banyak memberi perhatian terhadap perjalanan dan perkembangan dunia kepengacaraan di Indonesia. Undang-undang ini menjadi landasan yuridis bagi orang yang berprofesi sebagai advokat dan secara konstitusional merupakan pengakuan bangsa terhadap pentingnya profesi advokat untuk diatur sedemikian rupa sehingga mendatangkan manfaat, khususnya dalam penegakan hukum di negara Indonesia.

Pada prinsipnya Undang-Undang Dasar Negara Republik Indonesia Tahun 1945 menentukan secara tegas bahwa negara Indonesia adalah negara hukum. Prinsip negara hukum menuntut antara lain adanya jaminan kesederajatan bagi setiap orang di hadapan hukum (equality before the law). Oleh karena itu, Undang-Undang Dasar juga menentukan bahwa setiap orang berhak atas pengakuan, jaminan, perlindungan, dan kepastian hukum yang adil serta perlakuan yang sama di hadapan hukum. ${ }^{4}$ Pengakuan sebagai negara hukum kemudian diejawantahkan secara konkret dalam bentuk pengakuan terhadap nilai-nilai asasi manusia termasuk di dalamnya adalah perlindungan hukum terhadap semua orang.

http/www.blogster.com/khaerulhtanjung/sejarahhukum-advokat-indonesia
Negara hukum adalah suatu sistem kenegaraan yang diatur berdasarkan hukum yang berlaku dan berkeadilan yang tersusun dalam satu konstitusi, dimana semua orang dalam negara tersebut baik yang diperintah maupun yang memerintah harus tunduk pada hukum yang sama sehingga setiap orang diperlakukan sama tanpa memandang perbedaan warna kulit, ras, gender, agama, darah, dan keprcayaan, serta kewenangan pemerintah dibatasi berdasarkan suatu prinsip distribusi kekuasaan. ${ }^{5}$

Mengingat begitu banyak hukum yang mengatur seluruh aspek kehidupan masyarakat tentu tidak semua masyarakat bisa mengerti atau memahaminya. Padahal kita tahu bahwa masalah hukum itu bisa menimpa semua orang, akan tetapi tidak semua orang paham hukum, sehingga disini peran advokat atau pengacara diperlukan.

Pasal 5 ayat (1) undang-undang nomor 18 tahun 2003 tentang Advokat disebutkan, advokat berstatus sebagai penegak hukum, bebas dan mandiri yang dijamin oleh hukum dan peraturan perundang-undangan. Status advokat yang diakui sebagai penegak hukum oleh undang-undang secara langsung mensejajarkan profesi advokat dengan penegak hukum lainnya seperti polisi, jaksa, dan hakim. Pengakuan advokat sebagai salah satu penegak hukum membawa konsekuensi tersendiri bagi siapa pun yang menjalani profesi ini, tanggung jawab dan profesionalisme harus dimiliki oleh segenap advokat, mereka dituntut untuk tidak sekedar menjadi pembela klien akan tetapi bertanggung jawab atas ditegaknya hukum dan keadilan dalam setiap tingkatan pemeriksaan suatu perkara.

Dalam prakteknya profesi kepengacaraan ini tidak hanya dilakoni oleh advokat pada saat proses pemeriksaan pada tingkat penyidikan dan pemeriksaan di pengadilan (proses litigasi), akan tetapi peran

${ }^{4}$ Moh. Mahfud MD, Politik Hukum Hak Asasi Manusia di Indonesia”, dalam Jurnal Hukum, No. 14 Vol. 7, Agustus 2000, h. 2-3.

5 Munir Fuady, Dinamika Teori Hukum, Ghalia Indonesia, Bogor, 2007, h.1 
advokat juga terlihat di luar pengadilan. Kebutuhan jasa hukum advokat di luar proses pengadilan pada saat sekarang semakin meningkat, sejalan dengan semakin berkembangnya kebutuhan hukum masyarakat terutama dalam memasuki kehidupan yang semakin terbuka dalam pergaulan antar bangsa. Melalui pemberian jasa konsultasi, negoisasi maupun dalam pembuatan kontrak bagi pemberdayaan masyarakat serta pembaruan hukum nasional khususnya di bidang ekonomi dan perdagangan termasuk dalam penyelesaian sengketa di luar pengadilan. ${ }^{6}$ Advokat sebagai salah satu unsur sistem peradilan merupakan salah satu pilar dalam menegakkan supremasi hukum dan hak asasi manusia. Advokat merupkan profesi mulia yang erat hubungannya dengan kemanusiaan. ${ }^{7}$

Tanggung jawab advokat untuk mendidik dan memberdayakan masyarakat tentang hukum (rule of law) memang bukan perkara mudah. Hal ini disebabkan oleh tingkatan kesadaran hukum masyarakat yang tidak sama dengan presepsinya sebagai ciri khas dari suatu masyarakat.

Mahfud MD mengatakan bahwa produk dan proses penegakan hukum di Indonesia selama hampir 40 tahun terakhir (sejak tahun 1959 sampai tahun 1998) telah keluar dari kerangka berpikir dan acuan nilai-nilai atau paradigma Pancasila. Jika ditelusuri penyebabnya adalah tampilnya sistem politk yang tidak demokratis sehingga kekuasaan tersentralisasi di satu tangan. Oleh sebab itu upaya pembaruan hukum menjadi salah satu kebutuhan mendesak untuk dilakukan di awal-awal reformasi. $^{8}$

Pembaruan hukum bisa dilakukan oleh MPR, DPR, Pemerintah, Hakim (melalui lembaga peradilan), Pejabat Tata Usaha

\footnotetext{
${ }^{6}$ http/www.blogster.com/khaerulhtanjung/seja rah-hukum-advokat-indonesia.

7. Frans Hendra Winata, Advokat dan Masyarakat, Jentera Jurnal Hukum, Edisi 19, 2002, h. 48.

8. Moh. Mahfud MD, Membangun Politik Hukum, Menegakkan Konstitusi, Rajawali Press, Jakarta, 2012, h. 58.
}

Negara, bahkan para pemikir atau pakar-pakar hukum

Atas uraian tersebut diatas mendorong penulis untuk membahas dan memilih judul :"Peran Advokat Dalam Pembangunan Hukum Indonesia".

\section{Rumusan Masalah}

Berdasarkan uraian dalam latar belakang di atas, maka permasalahan yang akan dikaji dalam makalah ini, yaitu : Bagaimana peran advokat dalam pembangunan hukum ekonomi di Indonesia?

\section{METODE}

Penelitian ini merupakan penelitian kualitatif dengan Teknik deskriptif analitik dan menggunakan pendekatan penelitian normatif empiris. Dalam rangka memperoleh data yang relevan dengan kebutuhan penelitian ini,

\section{HASIL DAN PEMBAHASAN}

\section{Peran Lembaga Peradilan Dalam Pembangunan Hukum Nasional}

Istilah peradilan diartikan sebagai segala sesuatu mengenai perkara pengadilan. Sedangkan pengadian diartikan sebagai dewan atau majelis yang mengadili perkara atau bangunan tempat mengadili perkara. ${ }^{9}$

Menurut Arief B. Sidharta, hendaknya dibedakan antara peradilan dengan pengadilan. Peradilan merupakan institusi, pranata, dan proses, sedangkan pengadilan merupakan organisasi, struktur, dan badan peradilan. Dengan demikian, peradilan adalah pranata yang diciptkan atau tercipta di dalam masyarakat untuk menyelesaikan konflik atau sengketa secara imparsial, menggunakan kaidah hukum positif, berlaku umum, secara teratur, dan terorganisasi, serta objektif.". ${ }^{10}$

Sejak era tujuh puluhan, masyarakat hukum Indonesia familiar dengan ungkapan

${ }^{9}$ Pusat Bahasa Departemen Pendidikan Nasional, Kamus Besar Bahasa Indonesia, Edisi Ketiga, Balai Pustaka, Jakarta, 2002, h. 1277.

${ }^{10}$ Arief Sidharta dalam Dudu Duswara Machmudin, Kedudukan dan Peran Tindak Korupsi dalam Sistem Peradilan Pidana di Indonesia, DSP, Jakarta, 2013, h. 44. 
"hukum sebagai sarana pembangunan atau sebagai sarana pembaruan masyarakat". Suatu ungkapan yang memperoleh inspirasi dari Roscoe Pound "law as social enginering". ${ }^{11}$

Proses pembentukan hukum Indonesia dikenal dengan istilah pembaruan hukum, pembaruan hukum dan pembangunan hukum yang sejatinya memiliki makna yang sama bahkan beberapa ahli, pasca jatuhnya rezim orde baru menyebutnya dengan istilah reformasi hukum. Hukum perlu diperbarui karena hukum dalam arti yang sempit yaitu undang-undang selalu tertinggal oleh perkembangan masyarakat, cacat sejak lahir dan karena pembaruan hukum dalam pembentukan undang-undang selalu ditunggangi kepentingan atau (hidden agenda). ${ }^{12}$

Hukum, baik sebagai kumpulan norma (gejala normatif) maupun sebagai gejala sosial, adalah sebuah sistem. Ungkapan Ciceor "ubi societas ibi ius" (tidak ada masyarakat tanpa hukum). Demikian pula negara, baik sebagai organisasi kekuasaan (macht organisatie), atau sebagai organisasi hukum (rechts organisatie), maupun sebagai organisasi sosial (social organisatie) senantiasa memiliki sistem hukum. Tidak ada negara tanpa sistem hukum. Berdasarkan premis tersebut, semestinya makna awal dan sekaligus dasar pembangunan hukum (nasional), adalah membangun satu sistem hukum nasional yang mencerminkan watak, ciri, pandangan, fungsi, dan tujuan hukum secara nasional. Dalam konteks inilah harus dipahami bahwa pembinaan hukum nasional yang dilakukan melalui pembangunan hukum nasional adalah pembinaan sistem hukum nasional. ${ }^{13}$

Pembaru hukum sebagai sebuah proses memperbarui hukum yang mengandung

\footnotetext{
${ }^{11}$ Mochttar Kusumaatmadja, Hukum, Masyarakat, dan Pembinaan Hukum Nasional, Binacipta, Bandung, 1976, h. 8-9.

12 Tri Cahya Indra Permana, Pembaruan Hukum Administrasi Berbasis Pancasila Dan Tantangannya Di Era Globalisasi, dalam Varia Peradilan, Majalah Hukum Tahun XXXI, No. 369, IKAHI, Jakarta, 2016, h. 71.
}

pengertian mengubah hukum sebagai konsep law as o tool engineering yang dikemukakan oleh Roscoe Pound. ${ }^{14}$ Hukum harus menjadi penggerak ke arah perubahan yang lebih baik dari pada sebelumnya yang menurut Mochtar Kusumaatmadja mengatakan konsep pembaruan hukum merupakan asas hukum sebagai wahana pembaruan masyarakat. ${ }^{15}$

Pada saat ini kita hidup di era globalisasi. Hidup di era globalisasi, ditandai dengan adanya percepatan perubahan sosial yang didukung dengan terobosan-terobosan ilmiah dan teknologi. Dengan adanya perubahan yang cepat, terutama yang berkaitan dengan teknologi menjadikan mindset dan culturalset masyarakat berubah. Untuk menyikapi perubahan paradigma berhukum tersebut, menurut Supandi, menyatakan setidaknya ada 3 (tiga) hal yang harus diimplemantasikan oleh lembaga peradilan, yaitu :

Pertama, konsepsi penegakan hukum yang transparan, profesional dan akuntabel. Penegakan hukum yang bermartabat tidak dapat lepas dar keterbukaan informasi yang benar, jujur, dan tidak diskrimanatif selama proses persidangan berlangsung. Selain itu, keterbukaan (pengadilan) menghendaki adanya pengelolaan secara tepat guna, sehingga harus ditangani oleh aparatur yang profesional di bidangnya masing-masing aparatur yang melaksanakan penegakan hukum harus sesuai standar kompentensinya. Setiap kegiatan dan hasil akhir dari penegakan hukum ini harus dapat dipertanggungjawabkan sebagaimana yang ditentukan oleh peraturan perundangundangan.

Kedua, fungsi peradilan yang berbasis pelayanan publik. Pelayanan publik kaitannya dengan lembaga peradilan merupakan segala

13 Bagir Manan, Peranan Hukum Dalam Mewujudkan Cita-Cita Keadilan Sosial Menurut UUD 1945, dalam Varia Peradilan, Majalah Hukum Tahun XXIX No. 340, IKAHI, Jakarta, 2014, h. 7.

${ }^{14}$ Abdul Manan, Aspek-Aspek Pengubah Hukum, Kencana, Jakarta, 2005, h. 12

${ }^{15}$ Mochtar Kusumaatmadja,Fungsi dan Perkembangan Hukum dalam Pembangunan Nasional, Bina Cipta, Bandung, 1970, h. 12 
kegiatan dalam rangka pemenuhan kebutuhara. dasar sesuai hak sesuai hak-hak dasar setiap para pencari keadilan dan stakeholder atas segala bentuk pelayanan dan penyelenggaraan proses peradilan. Ukuran pelayanan disinb. seuai norma atau pedoman standar yang disepakati bersama-sama antara penyelenggara peradilan dan penerima pelayanan dan pihak yang berkepentingan. Jadi, penilaiannya diukur berdasarkan indeks kepuasan masyarakat pencari keadilan.

Ketiga, penggunaan teknologi informasi dalam lembaga peradilan. Keberadaan teknologi informasi di setiap organ negara merupakan suatu keharusan. Sebagai adagium yang menyatakan "tidak akan ada perbaikan mutu pelayanan publik tanpa inovasi, tidak ada inovasi tanpa aplikasi teknologi informasi dalam birokasi". Begitupun lembaga peradilan, sebagai organ negara atau birokrasi, akan dapat melayani publik pencari keadilan dengan prima apabila menggunakan teknologi informasi. ${ }^{16}$

Pengadilan akan bersih jika hakimnya juga bersih, karenanya faktor rekrutmen hakim menjadi sangat penting sebab dari dulu rekrutmen yang terbebas dari kolusi dan nepotisme akan bermuara pada hakim yang baik. Hakim yang baik hanya lahir dari suatu sistem rekrutmen yang baik. Hakim yang baik berpeluang besar berperilaku baik dan mengahasilkan putusan yang baik dan sebagai konsekuensinya adalah terwujud peradilan yang bersih. ${ }^{17}$ Rekrutmen hakim harus dilihat dari sisi memiliki kemampuan dibidang hukum, pengalaman memadai, memiliki integritas, moral, dan karakter yang baik. ${ }^{18}$

Bagir Manan menyatakan bahwa, kemampuan intelektualnya didukung oleh :

${ }^{16}$ Supandi, Capaian Pembaruan Oleh Mahkamah Agung RI Dan Pembentukan Persepsi Publik Terhadap Peradilan Indonesia, dalam Varia Peradilan, Majalah Hukum Tahun XXXII No. 371, IKAHI, Jakarta, 2016, h. 20.

${ }^{17}$ Amir Syarifuddin, Peran Komisi Yudisial dalam Mewujudkan Peradilan yang Bersih, Makalah Seminar, Jakarta, Manado, 2009, h. 2.

${ }^{18} \mathrm{M}$. Hatta Ali, Peran Hakim dalam Penemuan Hukum dan Penciptaan Hukum pada Era
Setiap hakim harus memahami konsep hukum maupun nonhukum agar dapat menentukan pilihan hukum yang akan dipergunakan dalam memutus perkara;

Penguasaan seluk beluk ketentuan hukum yang meliputi bentuk dan isi aturan hukum, pengertian hukum atau makna aturan hukum, hubungan sistematik antara berbagai ketentuan hukum, sejarah dan latar belakang suatu aturan hukum ;

. Penguasaan seluk beluk metode penerapan hukum seperti metode penafsiran, konstruksi, penghalusan hukum, dan sebagainya ;

Memahami lingkungannya (sosial, politik, ekonomi, budaya).$^{19}$

\section{Peran Advokat dalam Pembangunan Hukum di Indonesia}

Secara terminologi bahasa istilah peran berarti perangkat tingkah laku yang diharapkan dimiliki oleh orang yang beredudukan di masyarakat. ${ }^{20}$ Kata advokat, secara etimologis berasal dari bahasa latin, yaitu advocatus, yang berarti to defend, to call to one's and to vouch or warrant. Atau to speak in favour of or depend by argument, to support, indicate, or recommanded publicy. ${ }^{21}$

Advokat sendiri secara yuridis adalah orang yang berprofesi memberi jasa hukum, baik di dalam maupun di luar pengadilan yang memenuhi persyaratan berdasarkan ketentuan undang-undang nomor 18 tahun 2003 tentang Advokat. Jasa hukum sendiri diartikan sebagai jasa yang diberikan advokat berupa memberikan konsultasi hukum, bantuan hukum, menjalankan kuasa, mewakili, mendampingi, membela, dan melakukan tindakan hukum lain untuk kepentingan klien.

Secara garis besar sebagaimana ketentuan dalam undang-undang Advokat,

Reformasi dan Transformasi, Makalah dalam buku Bagir Manan, Ilmuwan dan Penegak Hukum, MA-RI, Jakarta, 2008, h. 201

${ }^{19}$ Bagir Manan, Menjadi Hakim yang Baik, MA-RI, Jakarta, 2007, h. 8.

${ }^{20}$ Pusat Bahasa, Op. Cit., h. 854.

${ }^{21}$ Soerjono Soekamto, Faktor-Faktor yang Mempengaruhi Penegakkan Hukum, Raja Grafindo Persada, Jakarta, 2002, h. 14. 
fungsi dan peranan Advokat antara lain sebagai berikut :

1. Memperjuangkan Hak-hak Asasi Manusia dan Negara Hukum Indonesia.

2. Melaksanakan Kode Etik Advokat.

3. Memegang teguh sumpah advokat dalam rangka menegakkan hukum, keadilan, dan kebenaran.

4. Menjunjung tinggia serta mengutamakan idealisme (nilai keadilan, kebenaran, dan moralitas).

5. Melindungi dan memelihara kemandirian, kebebasan, derajat dan martabat advokat.

6. Menjaga dan meningkatkan mutu pelayanan advokat terhadap masyarakat dengan cara belajar terus menerus (continuous legal education) untuk memperluas wawasan dan ilmu.

7. Memelhara kepribadian advokat karena profesi advokat merupakan profesi yang terhormat (officium nobile).

8. Menjaga hubungan baik dengan klien maupun dengan teman sejawat.

9. Memberikan pelayanan hukum (legal service)

10. Memberikan nasehat hukum (legal advice)

11. Memberikan konsultasi hukum (legal consultation)

12. Memberikan pendapat hukum (legal opinion)

13. Memberikan informasi hukum (legal information)

14. Membantu menyusun kontrak-kontrak (legal drafting)

15. Membela kepentingan klien (litigation)

16. Mewakili klien di muka pengadilan (legal representation)

17. Memberikan bantuan hukum dengan CumaCuma kepada masyarakat yang lemah dan tidak mampu (legal aid/pro bono publico). ${ }^{22}$

Advokat adalah profesi yang luhur dan mulia karena ia sering mendampingi kaum marginal dan papah yang terbelit dengan permasalahan hukum, banyak di antara advokat yang bekerja dengan tulus dan ikhlas tanpa pamrih. Profesionalisme dan keteguhan sikap ditujukan advokat pada saat mendampingi terdakwa di depan persidangan, ia tidak sekedar membela dan memastikan segala hak-hak terdakwa untuk dipenuhi akan tetapi ia juga bertanggung jawab terhadap suatu pola penegakan hukum yang objektif. Peran penting tugas seorang advokat telah dimulai sejak suatu perkara berada pada tahap penyidikan akan tetapi kehadiran advokat dalam proses ini cenderung pasif karena ia hanya bersifat mendampingi tersangka dalam pemeriksaan. Advokat sebagai penasehat hukum yang signifikan adalah ketika mendampingi terdakwa di depan persidangan, tahap demi tahap persidangan dilalui hingga putusan disampaikan/dibacakan oleh majelis hakim.

Setelah Indonesia merdeka, pada tahun 1964 lahir undang-undang nomor 19 tahun1964 tentang Pokok-Pokok Kekuasaan Kehakiman yang di dalamnya antara lain mengatur secara jelas tentang hak seseorang untuk mendapatkan bantuan hukum ketika terjerat suatu masalah hukum yang mengharuskannya berhubungan dengan lembaga penegak hukum. Lahirnya peraturan tersebut merupakan realisasi dari pelaksanaan Pasal 27 ayat (1) UUD 1945, yang menyatakan bahwa "setiap warga negara bersamaan kedudukanya dalam hukum dan pemerintahan dan wajib menjunjung hukum dan pemerintahan itu dengan tidak ada kecualinya".

Saat ini keberadaan advokat, sebagai pemberi bantuan atau jasa hukum kepada masyarakat atau klien yang menghadapi masalah hukum, semakin penting seiring dengan meningkatnya kesadaran masyarakat dan kompleksitas masalah hukum. Selain itu, advokat merupakan profesi yang memberikan jasa hukum saat menjalankan tugas dan fungsinya yang juga berperan sebagai pendampingi, pemberi advise hukum maupun menjadi kuasa hukum untuk dan atas dan atas nama klien.

Undang-undang No. 18 Tahun 2003 tentang Advokat dan Undang-undang No. 4 Tahun 2004 tentang Kekuasaan Kehakiman mengatur tentang keberadaan advokat dalam menangani suatu proses penegakan hukum

${ }^{22}$ Theodorus Yosep Parera, Op.Cit. h.6-7. 
bagi seorang tersangka. Pasal 1 butir 2 Undang-Undang Nomor 18 tahun 2003 tentang Advokat menjelaskan bahwa jasa hokum adalah jasa yang diberikan advokat berupa memberikan konsultasihukum, bantuan hukum, menjalankan kuasa, mewakili, mendampingi, membela dan melakukan tindakan hukum lain untuk kepentingan hukum klien. Disamping itu, advokat berkewajiban menegakan hukum dan keadilan. Undang-undang advokat telah memberi otoritas professional bagi advokat dalam memberikan pelayanan public sesuai dengan ilmu yang dimilikinya. ${ }^{23}$

Sedangkan pada butir 9 menjelaskan bahwa bantuan hukum adalah jasa hukum yang diberikan oleh advokat secara cumacuma kepada klien yang tidak mampu. Dalam konteks ini dapat terlihat pada Pasal 37 dan 38 UU No. 4 Tahun 2004 tentang Kekuasaan Kehakiman yang menjelaskan bahwa setiap orang yang tersangkut perkara berhak memperoleh bantuan hukum. Bahkan dalam perkara pidana, seorang tersangka sejak saat dilakukan penangkapan dan/atau penahanan berhak menghubungi dan meminta bantuan hukum.

Advokat bertugas tidak hanya menyelesaikan sengketa litigasi tetapi juga non litigasi. Bagi perkara litigasi, seorang advokat harus mendampingi tersangka yang melakukan tindak pidana pada semua tahapan proses peradilan. Adapun dalam hal keperdataan maka seorang advokat menerima kuasa dari seseorang yang sedang bersengketa. Oleh karena itu, tujuan yang dikehendaki advokat dalam perkara-perkara perdata harus mengutamakan penyelesaian dengan jalan damai dialihkan. ${ }^{24}$. Disamping itu, penegakan hukum yang obyektif memerlukan sikap integritas, etika, moral dan kejujuran penegak hukum, dimana tanpa sikap ini yang terjadi adalah suatu retrogresi hukum sehingga tidak pernah akan menghasilkan

\footnotetext{
${ }^{23}$ Marpaung Leden, Proses Penanganan Perkara Pidana Penyelidikan dan Penyidikan, Sinar Grafika, Jakarta, 2009, h. 15

${ }^{24}$ Fidel, Review UjianAdvokat, PT.Gramedia, Jakarta, 2010, h.74.
}

sesuatu yang diharapkan belakangan". 25 Dalam hal sikap masyarakat terhadap berperkara di pengadilan dan peran advokat, Frans Hendra Winarta seorang praktisi hukum, menceritakan pengalaman pribadinya saat di Jepang. Orang Jepang menganggap bahwa berperkara di pengadilan itu adalah suatu aib. Oleh karena itu, masyarakat Jepang umumnya selalu menghindari berperkara di pengadilan. Salah satu cara mereka menghindari berperkara di pengadilan adalah dengan membiasakan hidup teratur. Kalau seseorang atau perusahaan mengadakan kerjasama dengan orang atau perusahan lain selalu berusaha membuat kesepakatan atau ketentuan yang jelas. Oleh Karena itu, peran advokat di Jepang cukup menonjol. Hal ini berbeda dengan yang terjadi di Indonesia dimana berperkara di pengadilan telah dianggap sebagai hal yang lumrah. Oleh karena itu, keteraturan di Indonesia belum merupakan suatu budaya. Jika orang atau perusahan ingin mengadakan kerjasama dengan orang atau perusahaan lain maka hanya dibuat kesepakatan sekedarnya saja tanpa ada ketentuan yang jelas. Hal ini disebabkan ada 'istilah' dalam masyarakat Indonesia yaitu "yang penting jadi, persoalan belakangan". ${ }^{26}$

Berdasarkan berbagai dinamika yang terjadi di dunia peradilan selama ini maka sangat wajar kalau advokat harus bertindak secara professional menangani perkaraperkara yang dipercayakan kepadanya. Dalam konteks ini, mau tidak mau, suka atau tidak suka, para advokat sebagai pengemban profesi hukum harus terampil dalam mengekspresikan pemikirannya baik melalui tulisan seperti legal memorandum, legal opinion, menyusun gugatan, somasi, maupun secara lisan seperti menjawab pertanyaan

\footnotetext{
${ }^{25}$ Seno Adji dan Indriyanto, Humanisme dan Pembaruan Penegakan Hukum, PT. Kompas Media Nusantara, Jakarta, 2009, h. 241.

${ }^{26}$ Luhut P M. Pangaribuan DKK, Advokat Muda Indonesia, Sinar Harapan, Jakarta, 1996,h. 79.
} 
yang diajukan klien atau mengajukan pertanyaan di depan majelis hakim. ${ }^{27}$

Meningkatnya arus modal dan investasi asing, khususnya di antara pelakupelaku bisnis negara anggota ASEAN (interASEAN trade and investments), secara logis akan diikuti peningkatan kebutuhan jasa advokat atau konsultan hukum. Profesi ini penting dalam memberikan arah dan nasehatnasehat hukum, termasuk pendampingan yang dibutuhkan oleh para pelaku bisnis dengan benar dan terlindungi di Indonesia. Demikian pula sebaliknya, ketika pelaku bisnis Indonesia memutuskan untuk mengembangkan aktivitas investasi dan produksi, misalnya ke Thailand atau ke negara ASEAN lainnya. Pelaku bisnis Indonesia akan membutuhkan jasa dari advokat atau konsultan hukum yang memahami ketentuanketentuan hukum Thailand. Para advokat itu memberikan arah dan nasehat-nasehat hukum atau pendampingan agar pengusaha Indonesia dapat berbisnis dengan benar dan terlindungi di Thailand. . ${ }^{28}$

Saat ini banyak kasus hukum yang cenderung mengorbankan pihak rakyat dan hukum. Perkara pidana terhadap rakyat kecil seperti kasus Marsinah dan Udin tidak pernah terungkap dengan jelas. Penegakan hukum harus berdasarkan kepastian hukum, keadilan dan kemanfaatan. Kasus ketidak adilan dan kesesatan hukum menjadi praktik buruk dan kelemahan hukum di dunia peradilan selama ini pelaksanaannya. ${ }^{29}$ Pada hal ada otoritas yang dimiliki hakim yaitu dengan jalan penemuan hukum dimana cara menemukan hukum ini tidak ada pedomannya, petunjuknya, undang-undangnya, bahkan tidak ada Peraturan Mahkamah Agung (PERMA) atau Surat Edaran Mahkamah

\footnotetext{
${ }^{27}$ Arief Sidharta dalam Sentosa Sembiring, Penulusuran Hukum bagi Pengemban Profesi Hukum (Suatu Studi tentang Profesi Advokat sebagai

Pengemban Profesi Hukum, Lex Jurnalica, Vol. 6, No. 1, Desember 2008, h. 20.

${ }^{28}$ Soetanto Soepiadhy, Negeri ini Membutuhkan Advokat Pejuang, PT. Revka Petra Media Petra, Cetakan Pertama, 2010, h.152-153.

${ }^{29}$ O.C. Kaligis, Pengawasan terhadap Jaksa selaku Penyidik Tindak Pidana Khusus dalam
}

Agung (SEMA)-nya, sehingga penemuan hukum ini sepenuhnya diserahkan pada kebijakan atau kebebasan hakim. ${ }^{30}$

Sebagai profesi hukum, advokat mengemban tugas menegakkan keadilan dan meningkatkan martabat kemanusiaan, dengan demikian advokat merupakan officium nobile pekerjaan yang luhur. Sebagai profesi yang elegant advokat dituntut untuk dapat bekerja secara profesional yang terikat oleh etika profesi dan tanggung jawab standar keilmuan. Citra advokat sebagai profesi yang anggun akan ditentukan oleh etos profesi dalam arti sejauh mana komunitas advokat itu sanggup menerapkan standar etika serta ketrampilan berprofesi. ${ }^{31}$ Ketrampilan teknik berprofesi bagi advokat dapat diperoleh dari contining legal education, karena eksistensi komunitas advokat merupakan arena belajar bagi anggota profesi (advokat) untuk bersikap dan berperilaku sebagai profesional dalam dibidang hukum. ${ }^{32}$ Apalagi ketika advokat sudah masuk ke dalam tahap analisi perkara, maka advokat harus mampu menentukan kaidah hukum apa yang akan ia terapkan dalam perkara yang ditanganinya.

Advokat adalah bagian dari penegak hukum yang harus peduli dengan ditegakkan hukum yang berkeadilan, berimbang dan bertanggungjawab serta menjunjung tinggi nilai-nilai hak asasi manusia. Dalam kode etik advokat Indonesia, menyebutkan advokat sebagai profesi terhormat (officium nobile) yang dalam menjalankan profesinya berada di bawah perlindungan hukum, undang-undang dan kode etik, memiliki kebebasan yang didasarkan kepada kehormatan dan kepribadian advokat yang berpegang teguh kepada kemandirian, kejujuran, kerahasiaa, dan keterbukaan. Bahwa lebih lanjut Kode

Pemberantasan Korupsi, PT. Alumni, Bandung, 2006, h. 84.

${ }^{30}$ Eddy. OS. Hiariej, Asas Legalitas dan Penemuan Hukum dalam Hukum Pidana, Erlangga, 2009, h. .

${ }^{31}$ Artidjo Alkostar, Peran dan Tantangan Advokat dalam Era Globalisasi, FH UII Press, Cetakan Pertama, 2010, h.151.

${ }^{32}$ Ibid 
Etik Profesi Advokat Indonesia menentukan, profesi advokat adalah selaku penegak hukum yang sejajar dengan instansi penegak hukum lainnya.

Pasal 28 undang-undang nomor 18 tahun 2003 disebutkan bahwa profesi advokat yang bebas, mandiri dan betanggung jawab, karenanya advokat sebagai profesi hukum, dengan kedudukanya tersebut memerlukan suatu organisasi yang merupakan satu-satunya wadah profesi advokat sebagai organisasi advokat yang pada dasarnya organ negara dalam arti luas yang bersifat mandiri (independent state organ) yang juga melaksanakan fungsi negara.

Hingga saat ini amanat undangundang nomor 18 tahun 2003 tentang Advokat yang mensyaratkan agar advokat berada di bawah satu organisasi profesi belum terwujud, hal ini terlihat dari adanya dualisme lembaga/organisasi yang mewadahi para pengacara. Hal ini terkadang membawa persoalan tersendiri ketika kehadiran para pengacara di depan persidangan saling memberi koreksi terhadap keabsahan mereka antara satu sama lainnya. Dalam perkembangannya hal tersebut menjadi sebuah masa lalu dengan berbagai dinamikanya ketika Mahkamah Agung mengambil sikap tegas dengan menerbitkan peraturan yang pokoknya membolehkan masing-masing kubu untuk bertindak sebagai kuasa hukum/penasehat hukum dengan syarat-syarat tertentu.

\section{Tantangan Advokat Dalam Pembangunan Hukum di Indonesia}

Globalisasi perekonomian merupakan suatu keniscayaan yang tidak dapat lagi dipungkiri kehadirannya, sehingga yang paling tepat dilakukan bukanlah menghindarinya, melainkan mempersiapkan diri dengan sebaik mungkin untuk dapat menarik semaksimal mungkin manfaat dari setiap peluang yang diciptakan globalisasi tersebut. Termasuk juga untuk menangkal pengaruh-pengaruh negatif yang sangat

\footnotetext{
${ }^{33}$ Soetanto Soepiadhy, Op.Cit. h. 151.
}

berpotensi menggerus kemandirian suatu negara yang berdaulat.

Pernyataan di atas disampaikan oleh seorang Ahli Hukum Perdata Internasional Sunryati Harsono. Globalisasi perekonomian, seperti yang dijabarkan oleh Paul Hirst dan Grahame Thomson, telah meningkatkan interaksi yang berbasis nasional menjadi suatu kekuatan baru. Sistem ekonomi internasonal menjadi otonom dan terlepas dari ikatan nasional. Pasar dan kegiatan produksi benarbenar menjadi bersifat global dan lebih dikendalikan oleh kekuatan-kekuatan, pelakupelaku bisnis transnasional (transnational companies - TNCs). ${ }^{33}$

Tantangan advokat pada dasarnya banyak terletak pada diri advokat dan ikatan komunitas profesi seberapa jauh advokat dapat merespons permasalahan masyarakat lingkungannya. ${ }^{34}$ Tantangan yang lain adalah faktor iklim politik yang tidak kondusif untuk mengembangkan peran advokat, untuk itu perlu adanya sosialisasi fungsi keberadaan peran advokat baik terhadap pejabat maupun masyarakat umum. Tantangan tersebut akan semakin kompleks manakala keterampilan profesi dan semangat belajar dari pengacara tidak tumbuh sesuai dengan tuntutan jaman global, termasuk di dalamnya adalah penguasaan bahasa asing sebagai kunci pembuka komunikasi dengan relasi luar negeri. Untuk itu jaringan relasi dengan IBA (International BAR Association), $\mathrm{ABA}$ (American BAR Association), Lawyer Commitee For Human Rights dan sejenisnya merupkan kebutuhan pokok dalam era globalisasi.

Tantangan lain adalah sikap masyarakat yang belum mendukung profesionalisme, sehingga banyak waktu dan energi yang terbuang secara mubadzir dan tidak merangsang spirit atau untuk profesional, iklim penegakan hukum yang tidak menghargai profesionalisme. Untuk itu, perlu ada sikap kejujuran, keberanian, kecerdasan, kegigihan dan kesabaran dari advokat agar dalam menangani perkara secara 
profesional dapat sukses secara anggun (elegant) dan bermartabat. Sebagai profesi yang berposisi bebas dan cinta keadilan, advokat memiliki kewajiban moral dan tanggungjawab profesional untuk terus mengasah ketajaman pisau analisis ilmu hukum dan ilmu lain pendukung yang mempengaruhi penegakan hukum dalam kasus-kasus yang ditanganinya. Termasuk perkembangan hukum yang bersifat kosmopolitan dan berlaku secara internasional. Nilai tugas advokat antara lain pada misi memperjuangkan keadilan. ${ }^{35}$

Berkembangnya suatu peradaban terindikasi dari banyaknya pencapaianpencapaian yang dihasilkan oleh manusia dalam berbagai bentuk inovasi untuk membantu memenuhi kebutuhan hajat hidup. Dalam prespektif sosial sering terjadi suatu interaksi yang disatu sisi mendatangkan keuntungan namun di sisi yang lain terkadang terjadi benturan kepentingan antara manusia yang satu dengan manusia yang lain, konflik ini harus ditengahi dan hukum adalah salah satu alat yang efektif untuk menjadi pintu jalan keluar atas berbagai perseoalan yang dihadapi. Perangkat-perangkat hukum terkadang tidak cukup menjembatani atau membantu para pencari keadilan yang dapat disebabkan beberapa faktor di antaranya faktor ketersediaan tenaga (profesi hukum) itu sendiri maupun faktor kemampuan membayar jasa terhadap profesi hukum seperti advokat dan noataris misalnya.

Advokat juga harus mampu melakukan penulusuran hukum dan dokumentasi hukum, hal ini sangat diperlukan dan diakui eksistensinya agar setidaknya dapat memetakan perkara yang akan dan ditanganinya, sehingga setidaknya apa yang telah dihasilkan dari penulusurannya itu dapat berguna bagi kliennya, dan setidak-tidaknya

\footnotetext{
${ }^{35}$ Ibid, h. 170.

${ }^{36}$ Sri Mamudji, Penelusuran Literatur Hukum, Penerbit Fakultas Hukum Indonesia, Jakarta, 2007, h. 2

${ }^{37}$ Fatkhurohman, Penelusuran Hukum, Penerbit PKPA Widyagama, Malang, 2013, h.3.
}

dapat dipertanggungjawabkan secara teoritis maupun praktis.

Penelusuran, menurut Sri Mamudji secara umum dapat diartikan sebagai searching, mencari, meneliti, dan melihat kembali, ${ }^{36}$ sedangkan menurut Fatkhurohman, penelusuran adalah sebuah sarana untuk menemukan sesuatu melalui sebuah peranti atau alat atau instrumen yang dilakukan seseorang atau sekelompok orang yang bersifat aktif dan dinamis. ${ }^{37}$ Masih menurut Fatkhurohman, dokumentasi adalah pengumpulan hasil temuan dalam sebuah dokumen, baik yang berbasis non-gambar atau bergambar dari sebuah alat nonelektronik maupun elektronik. ${ }^{38}$

Secara sempit, tujuan dari penelusuran hukum adalah untuk mendapatkan informasi dari referensi berupa data sekunder yang dapat mendukung penelitian, sedangkan kegunaan penelusuran hukum adalah untuk mencari landasan teoritis, untuk mencari landasan yuridis, untuk mencari batasan dan pengertian yang jelas, dan untuk mencari bahan acuan atau rujukan.

Semua Penelurusan hukum dan dokumentasi hukum merupakan tantangan berat yang haus dihadapi dan dilakukan pengemban profesi hukum seperti advokat, mengingat pola pikir masyarakat melalui ilmu pengetahuan dan tehnologi sering kali meninggalkan hukum lebih jauh di belakang. ${ }^{39}$

Menurut Sentosa Sembiring, agar apa yang disampaikan klien itu menjadi jelas kasus posisinya, maka advokat perlu melakukan pemetaan masalah berdasarkan informasi yang telah diberikan klien. ${ }^{40}$

Ruang lingkup kerja advokat tidak terbatas di ruang lingkup pengadilan saja akan tetapi mereka juga dapat memberi advis/nasehat hukum kepada phak yang membutuhkan. Fakta imperis menunjukan

\footnotetext{
38 Ibid, h.4.

${ }^{39}$ Dudu Duswara Machmudin, Peran Advokat
} Dalam Penelusuran Hukum Dan Dokumentasi Hukum, Varia Peradilan, Majalah Hukum Tahun XXXII No. 372, IKAHI, Jakarta, 2016, h.10.

${ }^{40}$ Sentosa Sembiring, Op.Cit., h.22 
jika banyak warga yang kurang mampu dari sisi finansial akan tetapi terbelit permasalahan hukum yang barangkali tidak tersentuh oleh tangan advokat yang mau mendampingi mereka secara gratis. Pemahaman kita bersama jika keterlibatan advokat yang ditetapkan untuk mrndampingi klien berdasarkan penetapan pengadilan tidak hanya sebatas perkara pidana yang terdakwanya diancam dengan pidana tertentu yang wajib didampingi oleh penasehat hukum akan tetapi terhadap semua jenis perkara termasuk di dalamnya perkara perdata.

\section{PENUTUP}

1. Advokat sebagaimana juga warga negara yang lain memiliki hak untuk berekspresi secara bebas, berkeyakinan, berserikat dan berkumpul. Secara khusus pada advokat harus memiliki hak mengambil bagian dalam diskusi publik dalam yang berkenaan dengan hukum, penegakan keadilan, peningkatan dan perlindungan hak asasi manusia, bergabung dan membentuk organisasi lokal nasional maupun internasional, menghadiri pertemuan umum, tanpa mengalami halangan profesional dikarenakan tindakan upaya hukum yang dilakukan atau karena keanggotaan dalam organisasi yang sah menurut hukum. Dalam melaksanakan hak-hak tersebut advokat harus selalu bertindak sesuai dengan hukum dan menghormati aturan dan etika profesi hukum.

2. Advokat dalam melindungi kliennya dan dalam menegakkan keadilan harus berupaya menegakkan hak asasi manusia dan kebebasan dasar yang diakui dalam hukum nasional dan internasional dan selalu bersikap mandiri dan penuh ketekunan sesuai dengan hukum serta standar dan etika profesi.

3. Advokat juga harus mampu melakukan penulusuran hukum dan dokumentasi hukum, hal ini sangat diperlukan dan diakui eksistensinya agar setidaknya dapat memetakan perkara yang akan dan ditanganinya, sehingga setidaknya apa yang telah dihasilkan dari penulusurannya itu dapat berguna bagi kliennya, dan setidak-tidaknya dapat dipertanggungjawabkan secara teoritis maupun praktis.

\section{Saran}

Atas kesimpulan tersebut, dapat diajukan suatu saran atau rekomendasi agar pemerintah, organisasi advokat, lembaga pendidikan harus menjamin bahwa para advokat memiliki pendidikan yang cukup dan pelatihan serta diberi kesadaran tentang citacita dan kewajiban etika dari advokat dan tentang hak asasi manusia serta kebebasan dasar yang diakui oleh hukum nasional dan internasional.

$-000-$

\section{DAFTAR PUSTAKA}

Abdul Manan, (2005). Aspek-Aspek Pengubah Hukum, Kencana, Jakarta.

Alfaris, M. R. (2018). Peran Dan Tindakan Dewan Perwakilan Daerah Dalam Konteks Kekuasaan Dan Kewenangan Yang Merepresentasikan Rakyat Daerah. Conference on Innovation and Application of Science and Technology (CIASTECH) (p. 212). Malang: LPPM Universitas Widyagama Malang.

Amir Syarifuddin, (2009). Peran Komisi Yudisial dalam Mewujudkan Peradilan yang Bersih, Makalah Seminar, Jakarta, Manado

Arief Sidharta dalam Sentosa Sembiring, (2008). Penulusuran Hukum bagi Pengemban Profesi Hukum (Suatu Studi tentang Profesi Advokat sebagai Pengemban Profesi Hukum), Lex Jurnalica, Vol. 6, No. 1, Desember

Arief Sidharta dalam Dudu Duswara Machmudin, Kedudukan dan Peran Tindak Korupsi dalam Sistem Peradilan Pidana di Indonesia, DSP, Jakarta, 2013 
ArtidjoAlkostar, (2010). Peran dan Tantangan Advokat dalam Era Globalisasi, FH UII Press, Cetakan Pertama.

Bagir Manan, (2014). Peranan Hukum Dalam Mewujudkan Cita-Cita Keadilan Sosial Menurut UUD 1945, dalam Varia Peradilan, Majalah Hukum Tahun XXIX No. 340, IKAHI, Jakarta

Bagir Manan, (2007). Menjadi Hakim yang Baik, MA-RI, Jakarta.

Dudu Duswara Machmudin, (2016). Peran Advokat Dalam Penelusuran Hukum Dan Dokumentasi Hukum, Varia Peradilan, Majalah Hukum Tahun XXXII No. 372, IKAHI, Jakarta

Eddy.O.S.Hiariej, (2009). Asas Legalitas Penemuan Hakim dalam Hukum Pidana, Erlangga.

Fatkhurohman, (2013). Penelusuran Hukum, Penerbit PKPA Widyagama, Malang,

Fidel, (2010). Review UjianAdvokat, PT.Gramedia, Jakarta,. 
